\title{
Isoprene emissions modelling for West Africa: MEGAN model evaluation and sensitivity analysis
}

\author{
J. Ferreira ${ }^{1,2}$, C. E. Reeves ${ }^{1}$, J. G. Murphy ${ }^{3}$, L. Garcia-Carreras ${ }^{4}$, D. J. Parker ${ }^{4}$, and D. E. Oram ${ }^{1}$ \\ ${ }^{1}$ School of Environmental Sciences, University of East Anglia, Norwich, UK \\ ${ }^{2}$ CESAM \& Department of Environment and Planning, University of Aveiro, 3810-193 Aveiro, Portugal \\ ${ }^{3}$ Department of Chemistry, University of Toronto, Toronto, Canada \\ ${ }^{4}$ Institute for Climate and Atmospheric Science, University of Leeds, UK
}

Received: 27 January 2010 - Published in Atmos. Chem. Phys. Discuss.: 11 March 2010

Revised: 3 August 2010 - Accepted: 5 August 2010 - Published: 7 September 2010

\begin{abstract}
Isoprene emissions are the largest source of reactive carbon to the atmosphere, with the tropics being a major source region. These natural emissions are expected to change with changing climate and human impact on land use. As part of the African Monsoon Multidisciplinary Analyses (AMMA) project the Model of Emissions of Gases and Aerosols from Nature (MEGAN) has been used to estimate the spatial and temporal distribution of isoprene emissions over the West African region. During the AMMA field campaign, carried out in July and August 2006, isoprene mixing ratios were measured on board the FAAM BAe-146 aircraft. These data have been used to make a qualitative evaluation of the model performance.

MEGAN was firstly applied to a large area covering much of West Africa from the Gulf of Guinea in the south to the desert in the north and was able to capture the large scale spatial distribution of isoprene emissions as inferred from the observed isoprene mixing ratios. In particular the model captures the transition from the forested area in the south to the bare soils in the north, but some discrepancies have been identified over the bare soil, mainly due to the emission factors used. Sensitivity analyses were performed to assess the model response to changes in driving parameters, namely Leaf Area Index (LAI), Emission Factors (EF), temperature and solar radiation.

A high resolution simulation was made of a limited area south of Niamey, Niger, where the higher concentrations of isoprene were observed. This is used to evaluate the model's
\end{abstract}

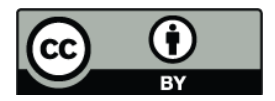

Correspondence to: J. Ferreira (jferreira@ua.pt) ability to simulate smaller scale spatial features and to examine the influence of the driving parameters on an hourly basis through a case study of a flight on 17 August 2006.

This study highlights the complex interactions between land surface processes and the meteorological dynamics and chemical composition of the PBL. This has implications for quantifying the impact of biogenic emissions on the atmospheric composition over West Africa and any changes that may occur with changing climate.

\section{Introduction}

Globally, isoprene (2-methyl-1,3,-butadiene) emissions are the largest source of reactive carbon to the atmosphere, completely dwarfing emissions of anthropogenic VOCs (volatile organic compounds) (Lamb et al., 1987). Isoprene is produced by many woody and some herbaceous plant species and is the dominant VOC released from vegetation (Guenther et al., 1995). It is one of the primary reactants of tropospheric chemistry over continental areas exerting strong influences over tropospheric ozone $\left(\mathrm{O}_{3}\right)$ and hydroxyl radical $(\mathrm{OH})$ chemistry, formation of organic nitrates and deposition of organic acids to rural areas (Fehsenfeld et al., 1992). Biogenic VOCs are also important in formation of secondary organic aerosols (SOA) (Kavouras et al., 1998). Model studies suggest biogenic emissions of VOCs from West Africa to be important for tropospheric ozone (Aghedo et al., 2007; Pfister et al., 2008). Understanding the role of isoprene on tropospheric chemistry is also important since natural emissions are expected to change with changing climate and human impacts on landuse (Sowden et al., 2007).

Published by Copernicus Publications on behalf of the European Geosciences Union. 
Light and temperature exert primary control over isoprene production and emission. Isoprene emission is undetectable in the dark, but begins rapidly upon illumination and is fully induced within $30 \mathrm{~min}$ (Loreto and Sharkey, 1990; Monson et al., 1991). Once induced, isoprene production responds rapidly to variations in photosynthetically active radiation (PAR). Monson et al. (1991) showed that during a light to dark transition, isoprene emission began dropping within $7 \mathrm{~s}$ and fell to zero within $5 \mathrm{~min}$.

In West Africa, biogenic emissions are expected to peak in the summer monsoon period when solar radiation is at its highest and when vegetation cover reaches its maximum. At this time biogenic emissions are expected to be the dominant source of VOCs for much of the region since biomass burning is mostly limited to the dry, winter season and anthropogenic emissions are mostly confined to the major coastal cities (RETRO Emission Database (http://retro.enes.org/)). Thus the West African Monsoon provides a relatively clean environment in which to study biogenic emissions and their regional effects on tropospheric chemical composition.

Previous in-situ observations in this region during the monsoon period have been confined to the MOZAIC programme, which involved measurements of $\mathrm{O}_{3}, \mathrm{CO}$ and total odd nitrogen $\left(\mathrm{NO}_{\mathrm{y}}\right)$ on commercial aircraft flying in the upper troposphere (Sauvage, et al., 2007) with vertical profiles as they descended and ascended into airports at Abidjan, Ivory Coast and Lagos, Nigeria (Sauvage, et al., 2005). Other measurement campaigns in this region have been limited to the dry season TROPOZ (Jonquieres et al., 1998) and DECAFE (Delmas et al., 1995).

As part of the AMMA (African Monsoon Multidisciplinary Analyses) project, the first airborne measurements of isoprene concentrations were made over West Africa (Bechara et al, 2009; Murphy et al, 2010) thus providing the first in-situ data set with which to make a large scale evaluation of the biogenic emission inventories being used in chemical transport model (CTM) studies of this area. The Model of Emissions of Gases and Aerosols from Nature (MEGAN) (Guenther et al., 2006) (MEGAN, 2010) is a state of the art dynamic emission model that is employed by many global and regional CTMs including some being used within the AMMA project. Previous observational constraints applied to the emissions calculated by MEGAN for Africa have been ground-based flux measurements at a few localised sites (e.g. fluxes from individual trees, or tower measurements from canopies) in southern (Otter et al., 2003; Greenberg et al., 2003; Otter et al., 2002; Guenther et al., 1996) and central Africa (Serca et al., 2001; Guenther et al., 1999; Greenberg et al., 1999; Klinger et al., 1998). This paper presents an evaluation of the emissions of isoprene calculated using MEGAN using observations of isoprene in the boundary layer over a large region of West Africa during the 2006 monsoon period and thus represents a significant advancement in the evaluation of MEGAN for this region.

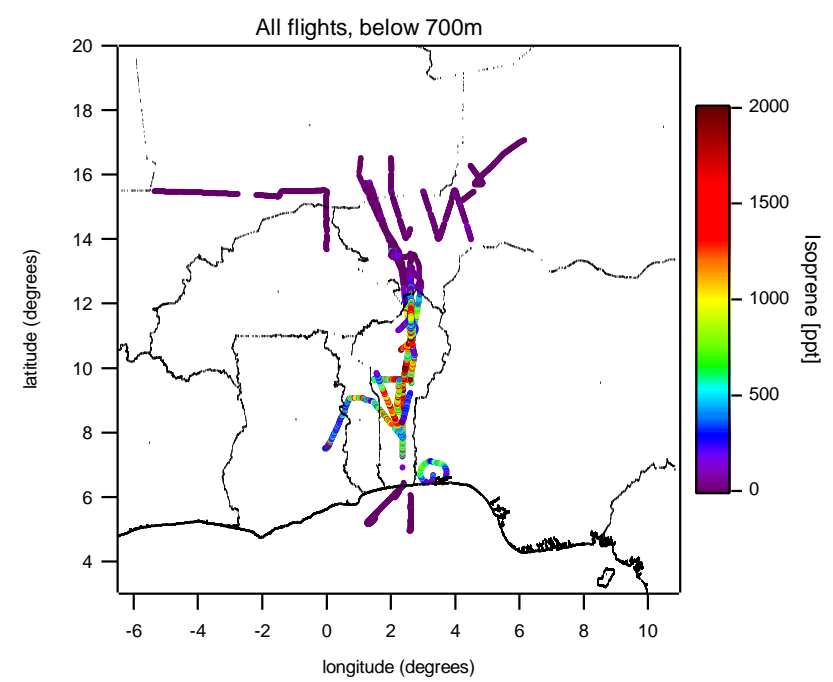

Fig. 1. FAAM BAe-146 aircraft flight tracks coloured by isoprene concentrations measured below $700 \mathrm{~m}$ during the AMMA field campaign in July and August 2006.

\section{Isoprene observations in West Africa}

During July and August 2006 a multi-aircraft campaign took place over West Africa to observe the chemical composition of the troposphere and lower stratosphere as part of the AMMA project. Measurements on board 5 research aircraft provide the first detailed, in-situ, characterisation of the chemical composition of the troposphere in this region (Reeves et al., 2010). This paper focuses on the isoprene mixing ratios measured aboard the UK Facility for Atmospheric Airborne Measurements (FAAM) BAe-146 research aircraft, which was based in Niamey, Niger. The measurements were taken during the 21 flights performed between the 17th of July and the 17th of August 2006 using a Proton Transfer Reaction Mass Spectrometer (PTR-MS) with a 10-15 second frequency and 15\% accuracy (Murphy et al, 2010).

Figure 1 presents the portions of the flight tracks of the BAe-146 below $700 \mathrm{~m}$ above sea level and respective isoprene concentrations observed during the AMMA field campaign. In using these observed concentrations to evaluate modelled emissions one has to apply some caution as transport, dilution and chemical transformation may impact atmospheric concentrations. It is therefore important to consider the nature of the observed data and how this might limit any emission model evaluation. These measurements were almost entirely taken during the daytime (98.4\%) when an altitude of $700 \mathrm{~m}$ was within the boundary layer and when isoprene has an atmospheric lifetime of around $1-2 \mathrm{~h}$ during the daytime, so cannot be transported far from its source. The typical wind speed in the boundary layer was around $10 \mathrm{~km} \mathrm{hr}^{-1}$ such that advection would only have displaced 


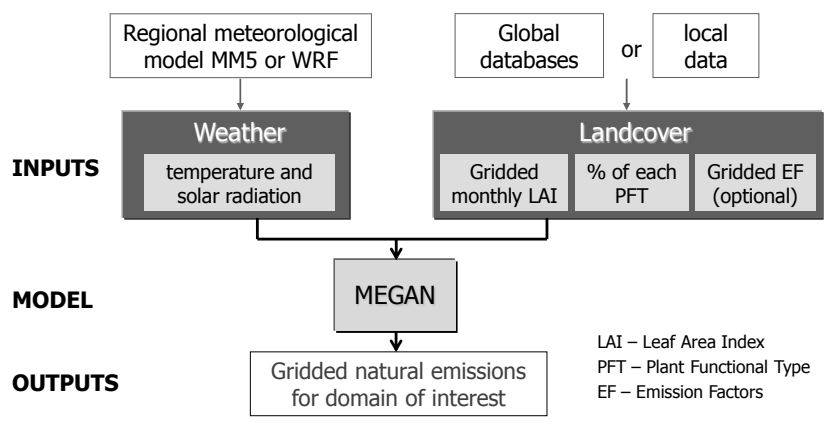

Fig. 2. MEGAN model structure including Input/Output information.

the emissions by about $10 \mathrm{~km}$ before the isoprene concentrations would have been reduced considerably through chemical reaction. A small percentage of the data (1.6\%) were collected at night (i.e. in hours of darkness) when $700 \mathrm{~m}$ would have been above the nocturnal boundary layer and when the chemical lifetime of isoprene would have been longer. Measurements made in the dark in the evening (Flight B219, 25 July) and early morning (B232, 14 August) show that the isoprene was transported about $1^{\circ}$ of latitude (60 nautical miles or $120 \mathrm{~km}$ ) northwards in the nocturnal flow, but that its mixing ratios had declined to around a third of their afternoon values. Therefore when looking at monthly patterns and at scales of a few $10 \mathrm{~s}$ of $\mathrm{km}$, it is reasonable to assume that the observed distribution of isoprene concentrations gives a good indication of the spatial distribution of emissions and as such provides a useful evaluation the model performance. When considering case studies of individual flights (even daytime flights), local environmental factors will affect observed concentrations and thus impact their comparison with modelled emissions, as discussed further in Sect. 5.

The aircraft mostly flew across an area ranging from 0 to $4^{\circ} \mathrm{E}$ longitude and 5 to $17^{\circ} \mathrm{N}$ latitude. The spatial variation of the isoprene measurements shows that the higher concentrations were measured between 8 to $12^{\circ} \mathrm{N}$. Broadly the concentrations drop off towards the coast in the south, and at 12 to $13^{\circ} \mathrm{N}$. However, between about 11.1 and $11.5^{\circ} \mathrm{N}$ there was a small region where low isoprene concentrations were persistently observed.

\section{Isoprene emissions modelling}

The Model of Emissions of Gases and Aerosols from Nature, MEGAN v2.04, has been applied to estimate the isoprene emissions over West Africa for July and August 2006.

MEGAN is an emissions model that estimates the net emission rate of isoprene and other trace gases and aerosols from terrestrial ecosystems into the above-canopy atmosphere at a specific location and time (Guenther et al., 2006). Figure 2 presents its input/output structure.
MEGAN requires two types of inputs in its default setup:

1. Landcover Data-monthly average Leaf Area Index (LAI), which is then averaged over the fraction of land area covered by vegetation (to give LAIv), Plant Functional Type (PFT), and emission factors (EF) at standard conditions. All of these are averaged for each grid location in the model domain. LAI values are needed for the month of the model simulation and the preceding month. These monthly LAI datasets are used to estimate the response of emissions to temporal variations in leaf age and LAI. Four different PFTs are considered by default in MEGAN-broadleaf trees, needle leaf trees, shrublands and herbaceous (including grass and crops). The emission factors can be considered within MEGAN as a function of the PFT at each location (PFT-specific emission factors) or pre-determined standard EFs for each location based on each type of vegetation (PFT) present, can be supplied as input.

2. Meteorological Data: Temperature and solar radiation variables output from the Meteorology-Chemistry Interface Processor (MCIP) are used to estimate the response of emissions to variations in temperature and light (Guenther et al., 2006). MCIP processes either WRF (Weather Research \& Forecasting Model) or MM5 (Mesoscale Model 5) output.

As a first approach, MEGAN has been applied to a regional domain with $40 \mathrm{~km}$ horizontal resolution (Sect. 3.1). A sensitivity analysis has also been performed aiming to evaluate the influence of the different input parameters to the isoprene emission estimates (Sect. 3.2). To have a more detailed picture of the isoprene emissions distribution in the area where the majority of the airborne measurements were made, MEGAN was run for a smaller domain at a higher resolution $(9 \mathrm{~km})$ (Sect. 3.3).

\subsection{Large scale MEGAN application over West Africa}

The regional domain, approximately 2000 by $2000 \mathrm{~km}^{2}$ wide (WA1), was defined taking into account the resolution of the input data available and the area where the BAe-146 flights were performed. The meteorological data were obtained from a WRF meteorological model regional (WRF, 2010) simulation for a period of 6 months in 2006 (from April to September), initialized with $1^{\circ} \times 1^{\circ}$ final global analysis (FNL) of the National Centre for Environmental Prediction (NCEP), and covering a $40 \mathrm{~km}$ horizontal resolution domain (Lat $-5^{\circ}$ to $20^{\circ}$ and Lon $-25^{\circ}$ to $25^{\circ}$ ) over West Africa with $3 \mathrm{~h}$ time resolution (Flaounas et al., 2010). Consequently the domain used to run MEGAN had $48 \times 48$ cells centred at $11.62^{\circ}$ Lat and $2.13^{\circ}$ Lon, with $40 \mathrm{~km}\left(\approx 0.36^{\circ}\right)$ horizontal resolution.

The MEGAN Community Data Portal (MCDP) includes datasets for LAIv for 2003 and PFT at $30 \mathrm{~s}$ horizontal resolution (i.e. $0.0083^{\circ}$ ) for the whole globe which were then 
averaged for the dimensions and resolution of the study domain. The PFT distributions vary according to plant type. Herbaceous species are spread throughout the domain although more concentrated in the middle latitudes of the domain. Needleleaf trees and shrubland fractions are greater at lower latitudes near the coast. Broadleaf tree fractions are very sparse in the study area.

Alternative LAI data sets for the years 2003 and 2006 from the MODIS satellite (MODerate resolution Imaging Spectroradiometer) were downloaded and converted into LAIv (using the MCDP PFT distributions). The MODIS LAI data were at $0.01^{\circ}$ horizontal resolution. The 2003 MODIS LAI was used for comparison with MCDP LAIv and the 2006 data were considered since the field observations of isoprene concentrations were made in 2006.

Figure 3 displays the three different sets of LAIv data used for this study. Comparing the two sources of LAIv for 2003 it can be seen that MODIS and MCDP LAI return similar fields, although the latter shows slightly higher values north of 12 degrees latitude. All LAIv fields present a band of considerably high values in the northern part of the domain. Moreover, from the two MODIS datasets, lower values of LAIv are found for 2006 compared to 2003. Generally, the area with highest LAIv values are observed in the southwest region of the study domain.

The pre-determined emission factors (EF), specific for each location, (for standard conditions of temperature and radiation) for some of the species considered by MEGAN are also available at the MCDP at $30 \mathrm{~s}$ horizontal resolution. These global data were averaged for the domain of interest as shown in Fig. 3 for isoprene. Isoprene emission factors decrease with latitude and are higher in the southeast part of the domain. High values of EF are given for some northern parts of this region, consistent with the LAIv fields, and as a consequence of the shrubland and herbaceous PFT spatial distributions. However, visual, subjective observations made on the BAe-146 flights in these regions suggested that very little vegetation was present. Certainly the observations of isoprene concentrations suggest very sparse coverage of isoprene emitting vegetation.

Figure 4 presents the results of the runs performed for domain WA1 (40 km resolution) using the three different sets of LAI data. These are also compared to the results obtained, for the year 2006, by Müller et al. (2007) who has estimated the global emissions of isoprene at $0.5^{\circ}$ horizontal resolution for each year between 1995 and 2006, using MEGAN and a detailed multilayer canopy environment model, i.e. the canopy has been divided into 5 layers, for the calculation of leaf temperature and visible radiation fluxes. Their calculation was driven by LAI from MODIS and meteorological fields (air temperature, cloud cover, downward solar irradiance, wind speed, volumetric soil moisture in 4 soil layers) provided by analyses of the European Centre for MediumRange Weather Forecasts (ECMWF).
Also in Fig. 4, the MEGAN estimated emissions are compared with observations of the mixing ratios of isoprene below $700 \mathrm{~m}$. The model reproduces the dropping-off of emissions at the Niger-Benin border in excellent agreement with the observations. However, unlike the observed concentrations which imply virtually no emissions in the north of the region, the current MEGAN runs suggest a band of emissions around $15-16^{\circ} \mathrm{N}$. This overestimation is not seen by Muller et al. Furthermore, MEGAN gives slightly greater emissions in the north (north of $12^{\circ} \mathrm{N}$ ) when using MCDP LAI 2003 as opposed to MODIS LAI. These results reflect the differences in distribution of LAI from the two different data sources, as seen in Fig. 3. The latitudinal gradient is discussed further in Sect. 4.

The differences in estimated emissions between July and August are mainly due to the temporal variation of meteorological inputs. The higher emissions in August can be explained by the slight increase in temperatures and solar radiation modelled by WRF. Muller's results show the reverse pattern which is likely to be due to the different meteorological data used. The observed concentrations are not obviously different between the 2 months. It should be noted that meteorological analyses over West Africa are poorly constrained due to the lack of observations and are thus highly uncertain. This is illustrated by the study of Agusti-Panareda et al. (2009) which demonstrated the impact of assimilating the additional radiosonde data collected during AMMA into the ECMWF analyses. There may be other factors (e.g. soil moisture, other meteorological parameters) which are not taken into account by MEGAN that altered the rates of isoprene emissions between July and August. Further the lifetime of the isoprene may have been different between the two months, which would have affected the observed concentrations.

\subsection{Sensitivity analysis}

A set of simulations were designed to examine the impact of four factors, namely EF, LAIv (from MCDP), radiation and temperature, on the spatial distribution of the monthly average emission fields. These were done using domain WA1. A run was performed in which all of these 4 parameters were held spatially and temporally constant to a median value and a further 4 runs were made in which all but one of these parameters were held constant. To illustrate the contribution of each driving parameter to the spatial distribution of the emissions Fig. 5 shows percentage differences between each of these 4 runs and the run where all these parameters are held constant for August.

The EFs and the LAI clearly have the greatest impact on the spatial distributions of the monthly averaged emissions, with emission differentials ranging from -85 to $158 \%$ and from -86 to $181 \%$, respectively. They both contribute to the strong gradient observed around $12^{\circ} \mathrm{N}$. However, it is the EFs that are responsible for the band of enhanced emissions 

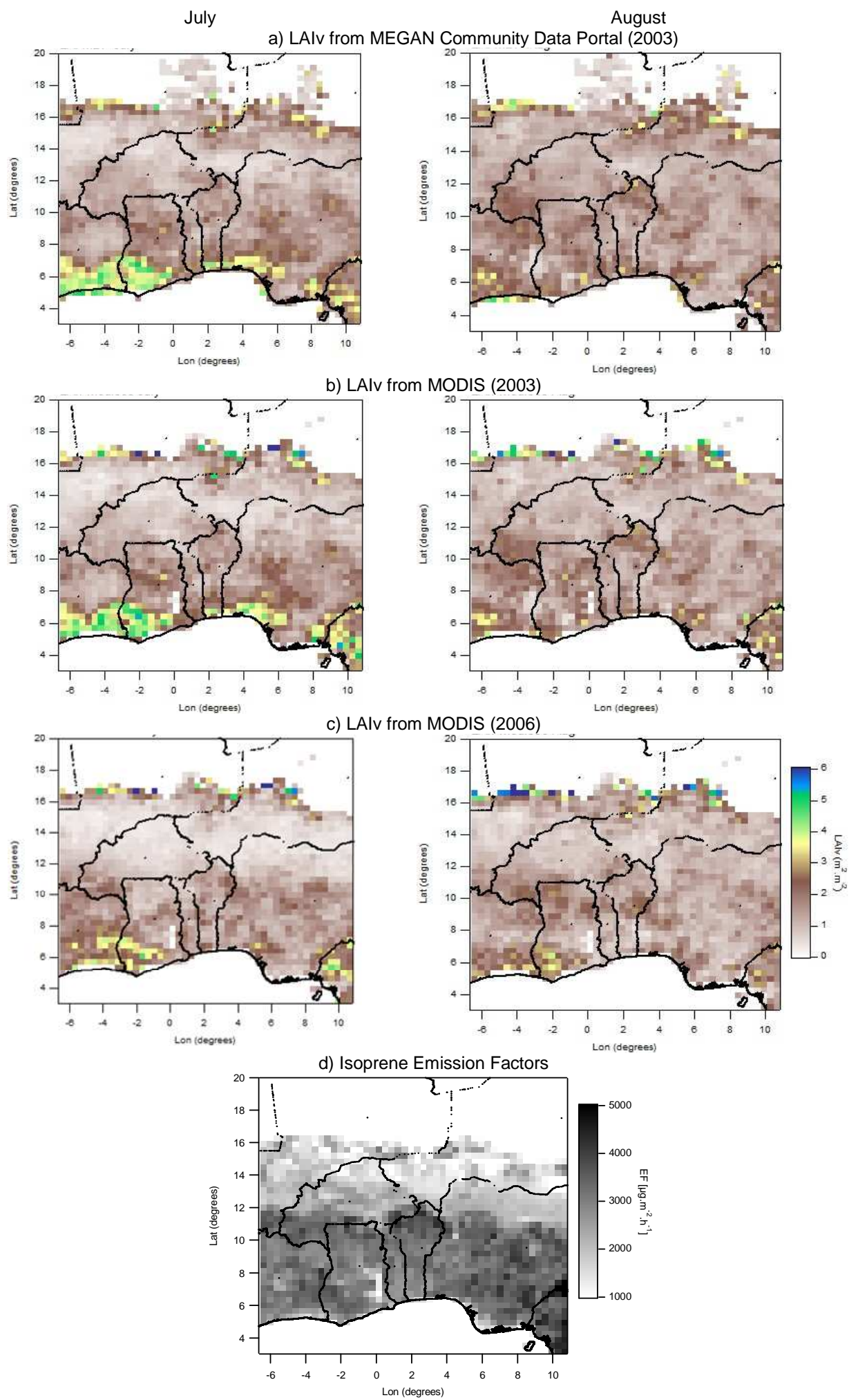

Fig. 3. Spatial distribution of the three different sets of LAIv data MCDP (2003) (a), MODIS 2003 (b), MODIS 2006 (c), and the isoprene emission factors for the $40 \mathrm{~km}$ horizontal resolution domain (d). 


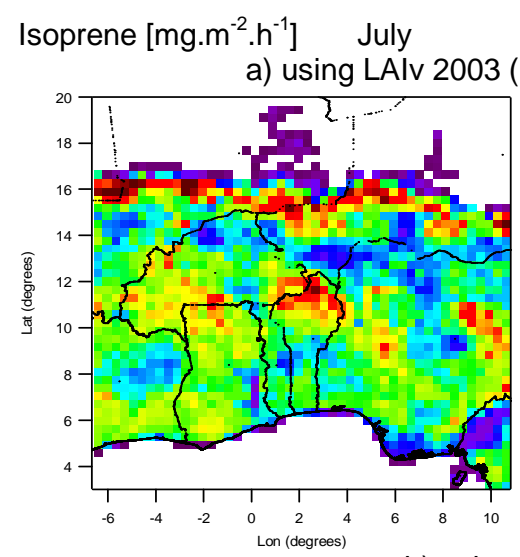

August

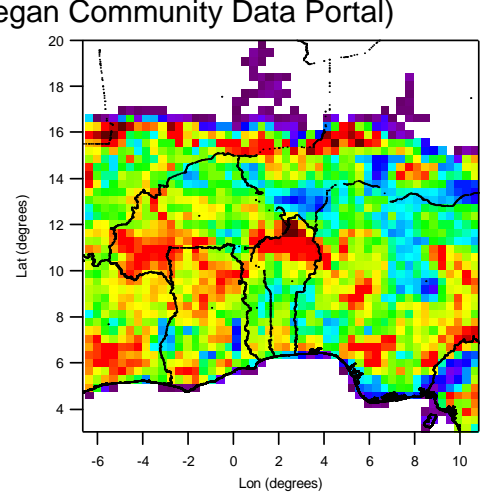

b) using LAlv 2003 (MODIS)
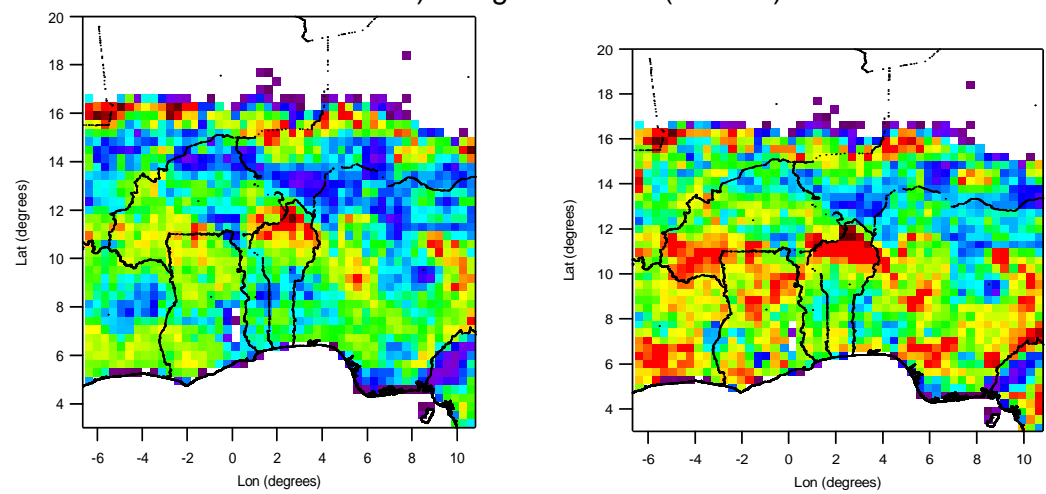

c) using LAIv 2006 (MODIS)
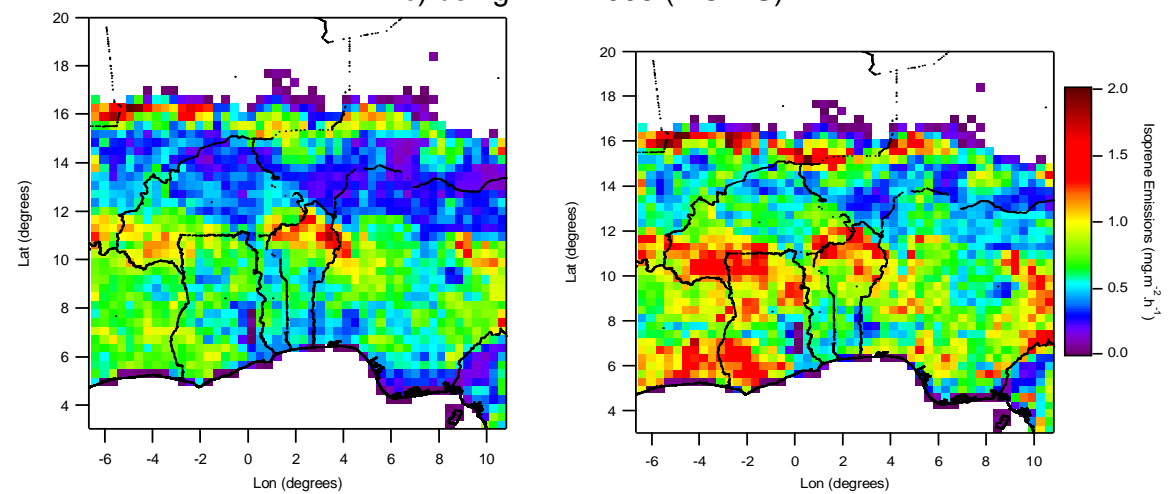

Fig. 4. Isoprene emissions ( $\mathrm{mg} \mathrm{m}^{-2} \mathrm{~h}^{-1}$ ) estimated by MEGAN (domain WA1) using three LAI fields from two different sources, LAI MCDP (a), LAI MODIS 2003 (b) LAI MODIS 2006 (c) and obtained by Müller et al., 2007, for the year 2006 (d), and isoprene concentrations (ppt) measured below $700 \mathrm{~m}$ (e). These are monthly averages and the data from the current study are calculated from 3 hourly output.

centred around $16^{\circ} \mathrm{N}$, which do not correspond to observed concentrations of isoprene. The meteorological parameters do not contribute more than 10 to $20 \%$, in terms of spatial variation, to the simulated isoprene emissions when monthly averages are considered.

\subsection{MEGAN application at higher resolution}

Although the results presented so far provide an assessment of MEGAN on a large scale, they are not of high enough resolution to examine some of the smaller scale features exhibited in the observational data. The spatial resolution of $40 \mathrm{~km}$ and temporal resolution of $3 \mathrm{~h}$ were necessitated by the meteorological data used. To bypass this limitation the meteorological model MM5 has been applied to West Africa to get meteorological fields with higher spatial and temporal resolution. The PSU/NCAR mesoscale model MM5 is a limited-area, non-hydrostatic model with a multiple nesting capability, designed to simulate or predict mesoscale atmospheric circulation (Dudhia, 1993, Grell et al., 1994). MM5 
d) MEGAN results from Muller et al., 2007
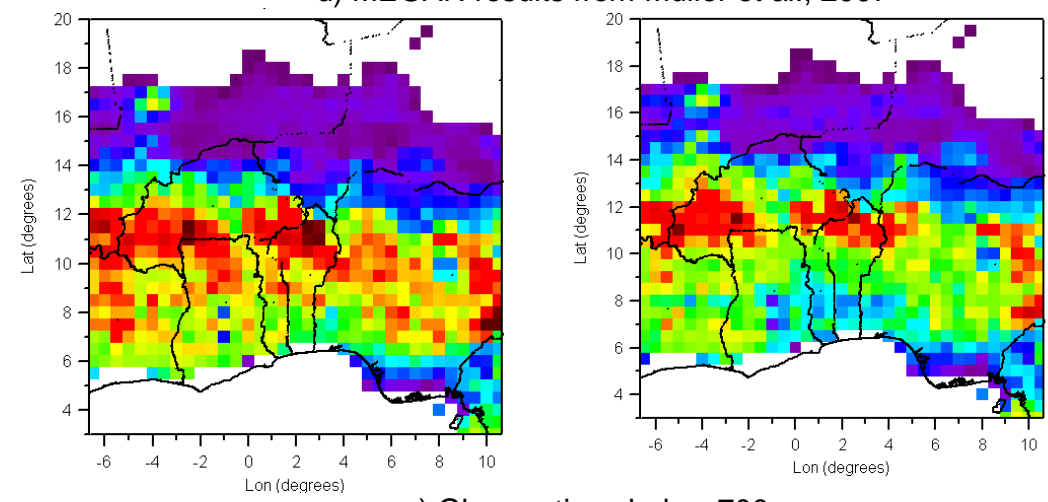

e) Observations below $700 \mathrm{~m}$
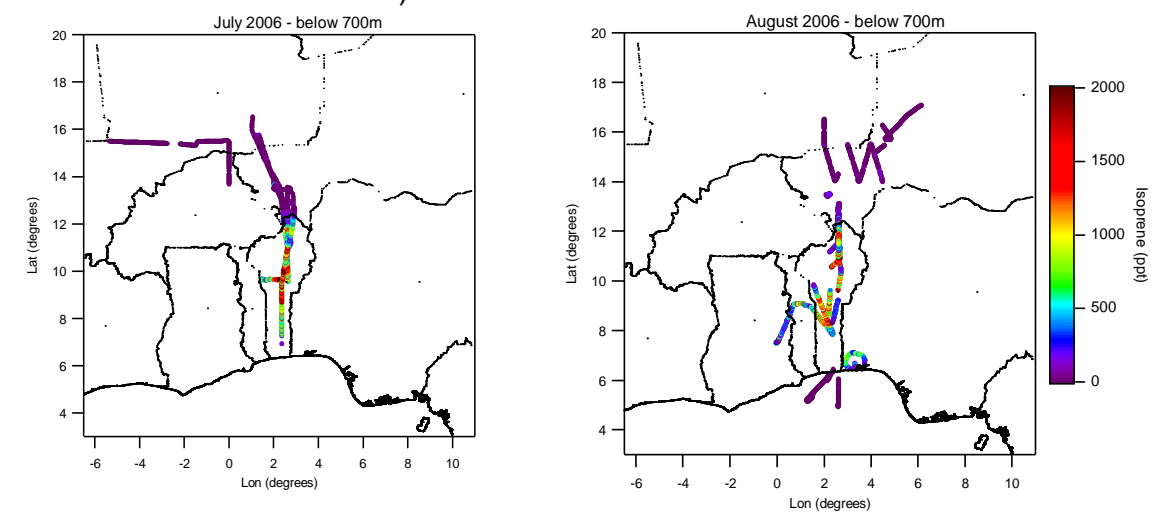

Fig. 4. Continued.

has been used worldwide including the area of interest of this study, as a climatological application (Sijikumar et al., 2006).

MM5 has been run for 2 domains (27 and $9 \mathrm{~km}$ resolution respectively) using the two-way nesting capacity. The meteorological run has been performed for a two month period (July and August 2006) by consecutive three day simulations, with a spin-up of $6 \mathrm{~h}$ each, initialized with NCEP/FNL $1^{\circ}$ resolution global data (NCEP, 2008). Based on the second MM5 domain, with $9 \mathrm{~km}$ resolution, a MEGAN domain was defined (WA2). MM5 returns the hourly temperature and radiation 2-D fields for the whole simulated period (July and August) needed for the MEGAN simulation.

In this higher resolution MEGAN simulation, apart from the meteorological fields, all the other input sources were the same as the lower resolution MEGAN simulation. Figure 6 shows the LAIv and EF fields averaged for the $9 \mathrm{~km}$ resolution domain based on the $0.01^{\circ}$ LAI from MODIS 2006. Figure 7 compares the results for domain WA2 with the isoprene emission estimates for domain WA1, both using LAI from MODIS 2006. The total monthly isoprene emissions estimated were higher for the higher resolution application: $0.43 \mathrm{Tg}$ as opposed to $0.10 \mathrm{Tg}$ for July, and $0.31 \mathrm{Tg}$ versus $0.12 \mathrm{Tg}$ for August, for the area of WA2 domain $\left(\approx 825000 \mathrm{~km}^{2}\right)$. North of $12^{\circ} \mathrm{N}$, the higher resolution model gives lower emissions, whilst south of $12^{\circ} \mathrm{N}$ it gives higher emissions, which are spread most of the way to the coast, unlike the lower resolution run which has high emissions largely confined to northern Benin. This is true for both months, but particularly so for July. At high resolution, the spatial distribution more closely resembles that of the observed concentrations. A feature that was repeatedly observed during several flights was low isoprene mixing ratios in a small area in northern Benin around $11.1-11.5^{\circ} \mathrm{N}$. Global land cover data (Source Data: ${ }^{(} \mathrm{ESA} / \mathrm{ESA}$ Globcover Project, led by MEDIAS-France/POSTEL) suggest this area to be mostly rainfed cropland as opposed to forest or shrubland in surrounding areas. The high resolution model run also shows a similar feature in the calculated emissions that is present both for July and August.

The explanation for these changes is likely to be a combination of the higher resolution LAI and EF along with the change in the meteorological inputs. For example the minimum observed in northern Benin is captured by low EFs in the higher resolution input (Fig. 6) that is averaged out at the lower resolution (Fig. 3). Regarding the meteorological data, on average the temperature and radiation modelled by MM5 are slightly lower than estimated by WRF, which should lead to lower emissions (i.e. the opposite effect). However, it appears that the greater spatial and temporal (hourly) variability of the higher resolution run and the fact that isoprene 
a)

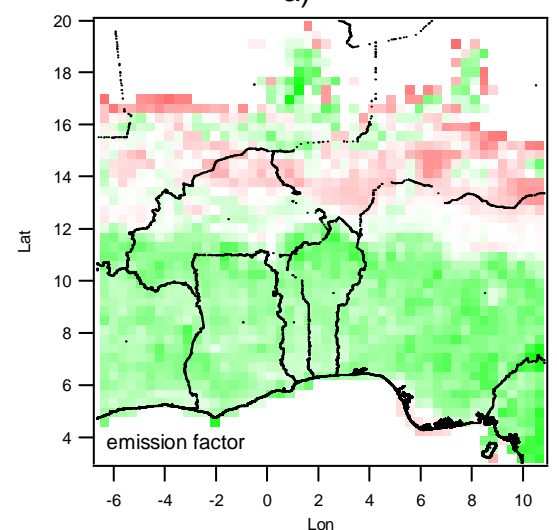

c)

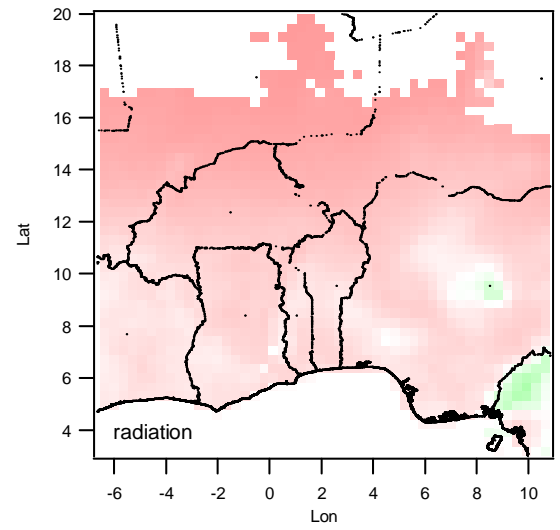

b)

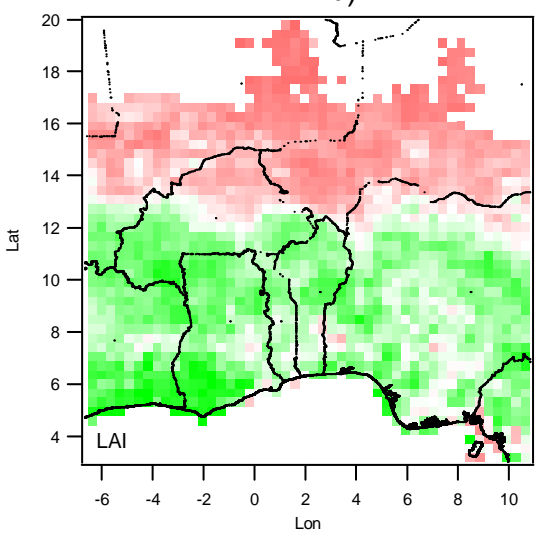

d)

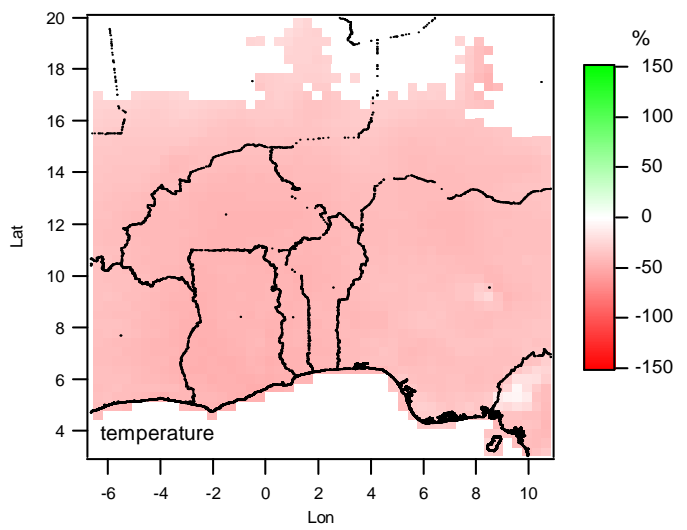

Fig. 5. Spatial distribution of the differentials in percentages obtained for August between each one of the four hypothetical runs performed with all but one variable constant and a run where all variables are constant in space and time, (e.g. plot a) refers to the differences in percentage between the run with all variables constant except emission factors and the run with all inputs constant). (a) emission factors, (b) LAI, (c) radiation and $(\mathbf{d})$ temperature.

emissions are non-linear with respect to temperature, leads to higher emissions, whereas averaging these inputs in the lower resolution run leads to lower emissions. This is consistent with the work of Ashworth et al. (2010), who found that increasing the temporal resolution of the meteorological data used to calculate emission isoprene fluxes with MEGAN led to larger global fluxes. Further that these changes varied regionally and that the tropics, including the region of West Africa considered in the current study, exhibited some of the largest increases when going from 3-hourly to hourly input data. In terms of temporal evolution the simulation for WA2 returns higher isoprene emissions in July which was not observed in the previous simulation but is in agreement with Müller's results (Müller et al., 2007). This behaviour reflects a decrease in radiation levels between July and August in the MM5 data.

\section{Monthly latitudinal variations}

The model emissions from the four simulations performed (three for domain WA1 and one for domain WA2), along with those from Müller et al., have been averaged for the longitude range $2-3^{\circ} \mathrm{E}$ to better compare them with the observations (averaged for 0 to $3^{\circ} \mathrm{E}$, but note that most are between $2-3^{\circ}$ E) (Fig. 8). It should be noted that the observed concentrations at any given latitude exhibit a large range of values. This can mostly be attributed to very small scale variations that may be due to variations in vegetation, rates of mixing within the planetary boundary layer, or cloud cover. Also the observations were made at different times of day, with higher values generally observed close to midday (see below).

Despite the observed mixing ratios suggesting virtually no emissions over the bare soil (north of $12^{\circ} \mathrm{N}$ ), all of the present study WA1 simulations suggest large emissions in this region (due to the emission factors used; Sect. 3.2). Muller's simulation shows low emissions in this region apart from a small peak around 14 degrees. The WA2 simulation stops around $15^{\circ} \mathrm{N}$, but it gives lower emissions than any of 


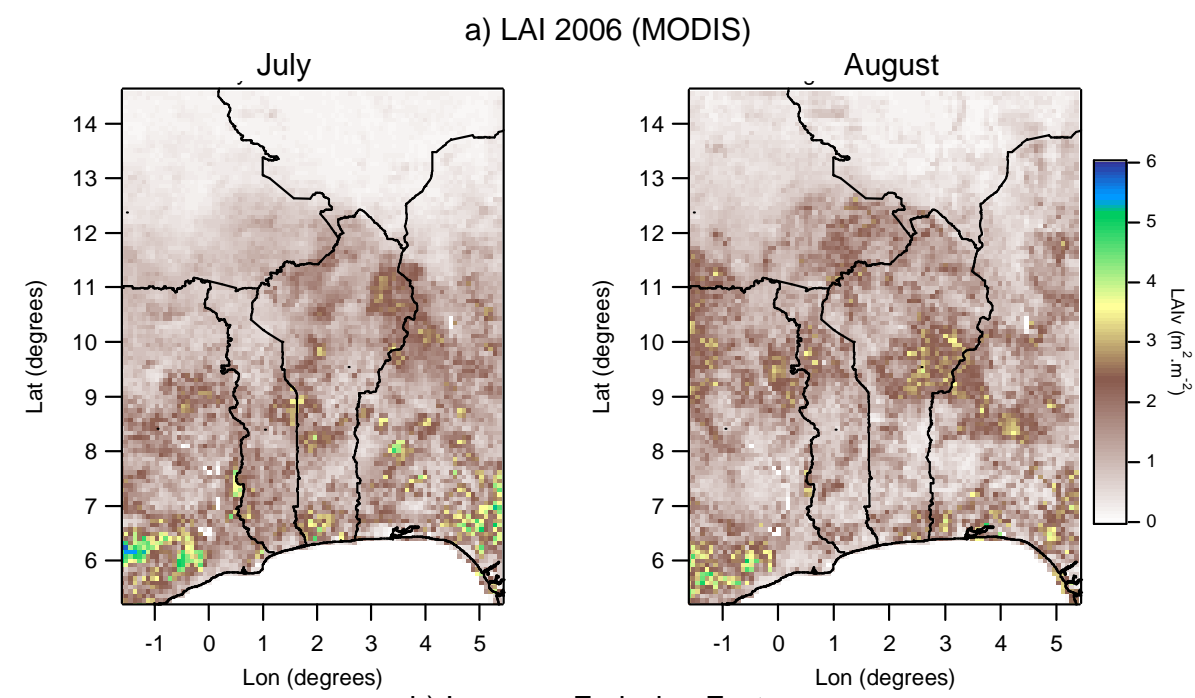

b) Isoprene Emission Factors

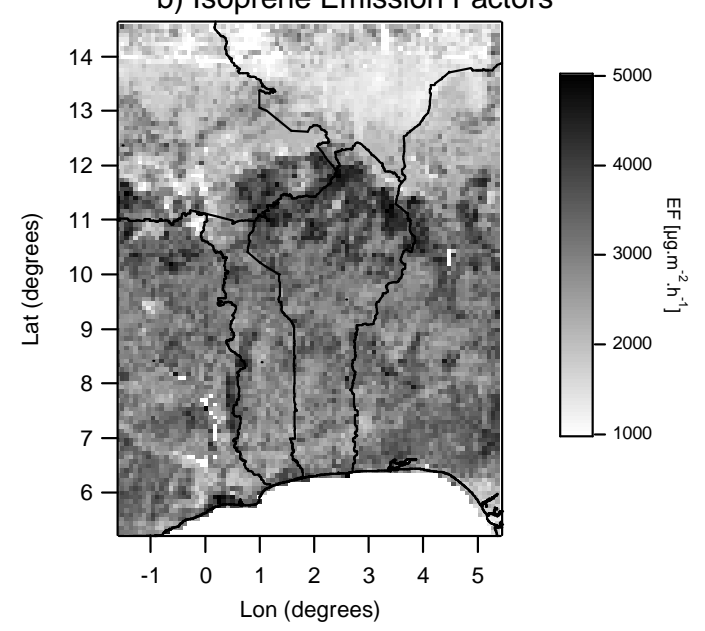

Fig. 6. Spatial distribution of LAIv data from MODIS (2006) (a), and the isoprene emissions factors for the $9 \mathrm{~km}$ horizontal resolution domain (b).

the other simulations between and 13 and $15^{\circ} \mathrm{N}$, more consistent with the observed mixing ratios.

The WA1 simulations estimate relatively low emissions between 7 to $10^{\circ} \mathrm{N}$ compared to 10 to $12^{\circ} \mathrm{N}$, which is not implied by the observed isoprene emissions which show that high concentrations can exist at all of these latitudes. The WA2 simulation however results in a more even distribution of emissions between 7 to $12^{\circ} \mathrm{N}$. Further the WA 2 run also gives a slight dip in emissions in the region of rainfed cropland just north of $11^{\circ} \mathrm{N}$, which is coincident with the lower mixing ratios observed on repeated flights at this latitude.

\section{Hourly variability - case study}

The comparative analysis of the isoprene emission estimates for the two resolutions simulated by MEGAN has revealed that the meteorological inputs may have a considerable influence on the emissions modelling, especially at a high tem- poral resolution. A case-study analysis has been performed aiming to contribute to a better understanding of these phenomena.

The results for 17 August 2006 have been investigated more deeply to analyse the temporal variation of measured and simulated parameters. On that day, the aircraft flew below $700 \mathrm{~m}$ altitude between 13:45 and 14:30 (low run of flight B235). Figure 9 presents the hourly fields of isoprene emissions estimated by MEGAN at $9 \mathrm{~km}$ horizontal resolution, and temperature and radiation simulated by MM5, for the corresponding hours of the low run. The surface fields show that the isoprene emissions are clearly driven by the simulated radiation. The areas where the radiation is higher correspond to higher emissions. Although emission and radiation patterns change from hour to hour, the spatial variability of the radiation is continuously represented in the spatial distribution of the isoprene emission estimates for any hour. The temperature drives the overall magnitude of the 
a) $40 \mathrm{~km}$ resolution

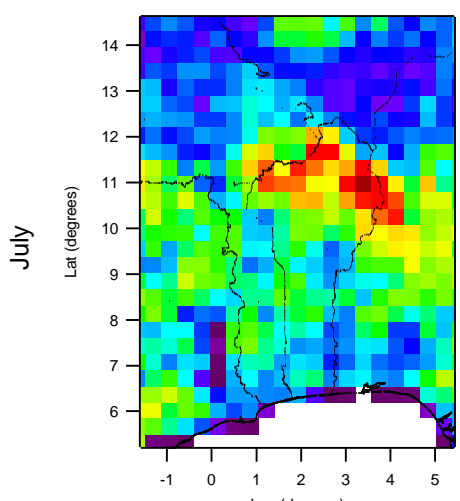

Lon (degrees)

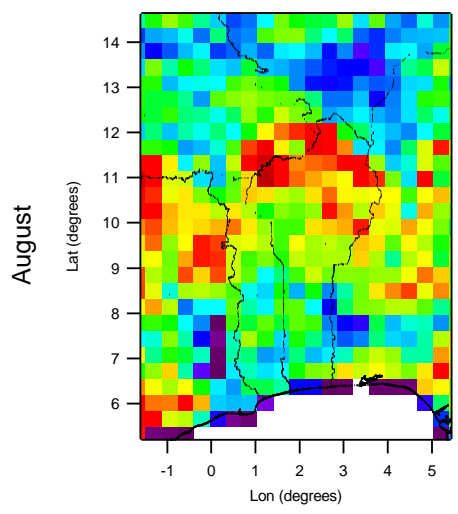

b) $9 \mathrm{~km}$ resolution
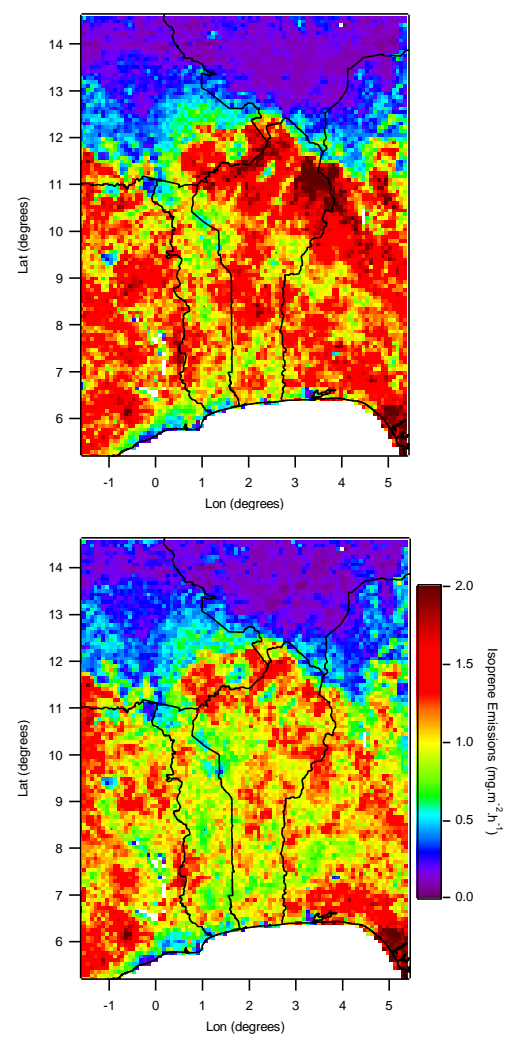

c) Observations
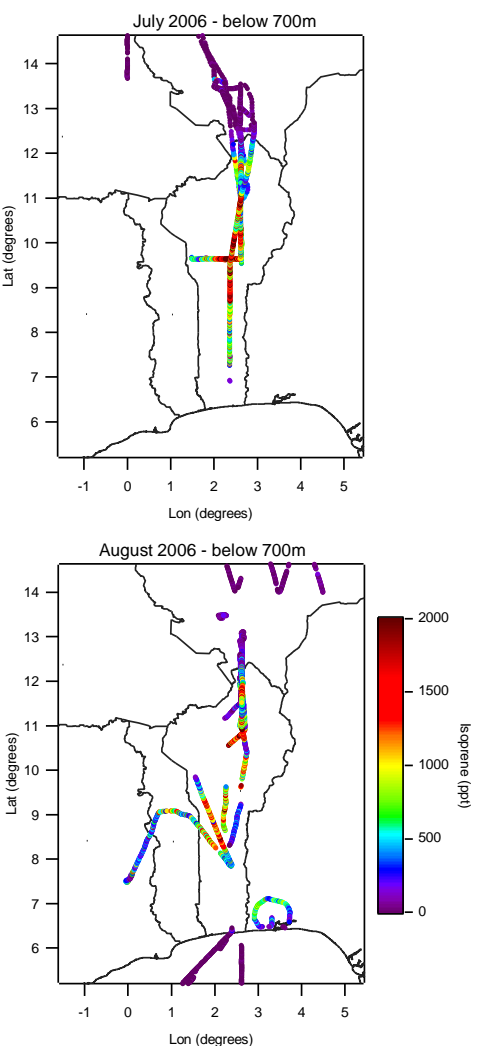

Fig. 7. Isoprene emission ( $\mathrm{mg} \mathrm{m}^{-2} \mathrm{~h}^{-1}$ ) estimates for (a) 40 and (b) $9 \mathrm{~km}$ resolution MEGAN applications and (c) isoprene concentrations (ppt) measured during the AMMA Project field campaign on board the FAAM BAe-146 aircraft in July and August 2006.

emissions (a temperature increase leads to higher emissions), but this meteorological parameter has little impact on their spatial variability, since the temperature itself does not vary much spatially (differences between adjacent grid cells are not higher than 3 to 5 degrees).

In an attempt to evaluate the MM5 behaviour, MeteoSat infrared images and cloud classification for the flight day and times were analysed and are broadly in agreement with the MM5 radiation maps. However, this is not true if one does a cell by cell verification. Simulating the development of convective systems and thus clouds over West Africa is difficult, with the results often being model dependent (e.g. Sijikumar, et al., 2006; Flaounas et al., 2010), and thus a source of uncertainty for emission estimates.

The impact of radiation on the modelled isoprene emissions is further demonstrated in Fig. 10, where the model emissions and radiation extracted along the position of the flight track are plotted as a function of latitude for 14:00 UTC and 15:00 UTC. It is noticeable how the modelled radiation changes markedly along the flight track between the two hours and that the calculated emissions change in a similar manner.
Also in Fig. 10 are data collected on board the aircraft during this low level run. The observed isoprene mixing ratios exhibit several features that are not specifically related to temperature or radiation (Garcia-Carreras et al., 2010): there was a large scale downdraft around $10.5^{\circ} \mathrm{N}$ (associated with a mescoscale convective system (MCS) cumulonimbus cells to the west of the flight track), which is characterised by higher ozone mixing ratios, lower specific humidities (not shown) and lower temperatures (Fig. 10); the vegetation cover changes dramatically at around $12^{\circ} \mathrm{N}$ with rainfed croplands to the north and mostly shrubland and forest to the south, except between 11.0 and $11.5^{\circ} \mathrm{N}$ where there is rainfed cropland. The downdraft means that the air sampled around $10.5^{\circ} \mathrm{N}$ came from the free troposphere and thus we should exclude it from a comparison with the calculated emissions. The model has been shown to capture, to some degree, the features associated with the vegetation cover (see above), however this case study illustrates the strong influence of the model radiation. The emissions calculated for 15:00 UTC show some similarities to the observed isoprene mixing ratios, with lower values between 11.0 and $11.5^{\circ} \mathrm{N}$ and north of $12^{\circ} \mathrm{N}$, but at this time the radiation follows a similar pattern. At 14:00 UTC, when the model radiation is 


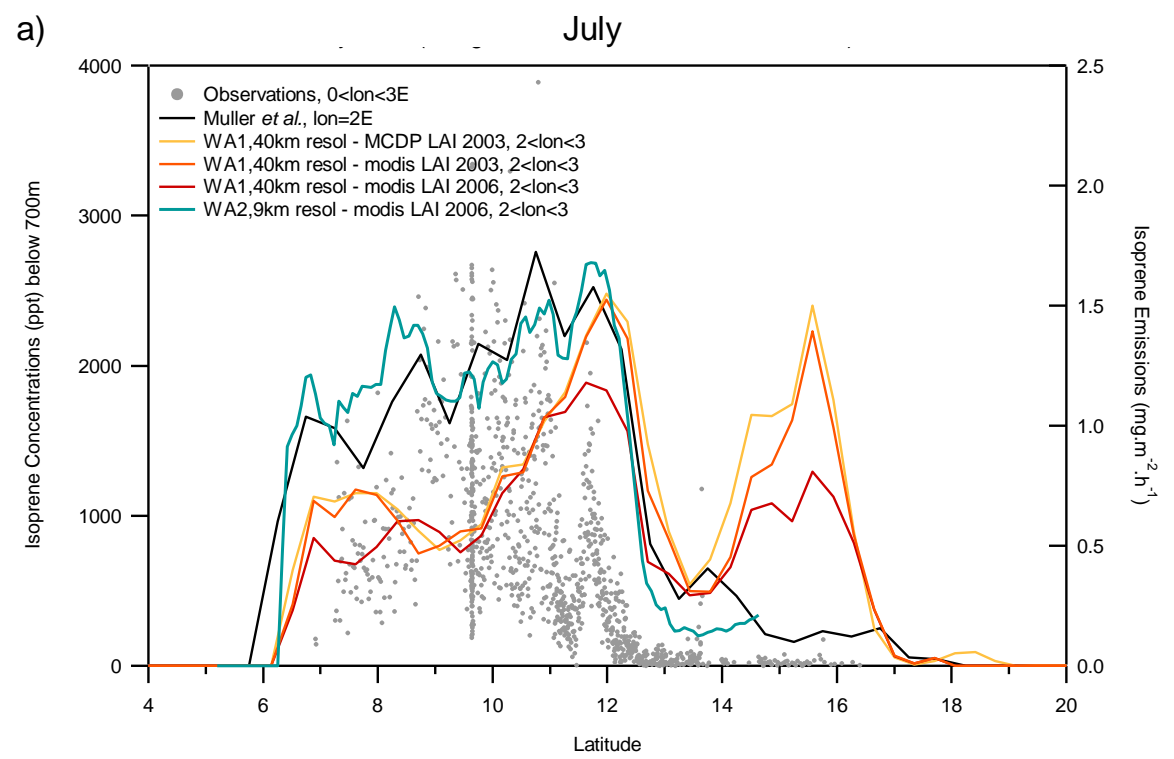

b)

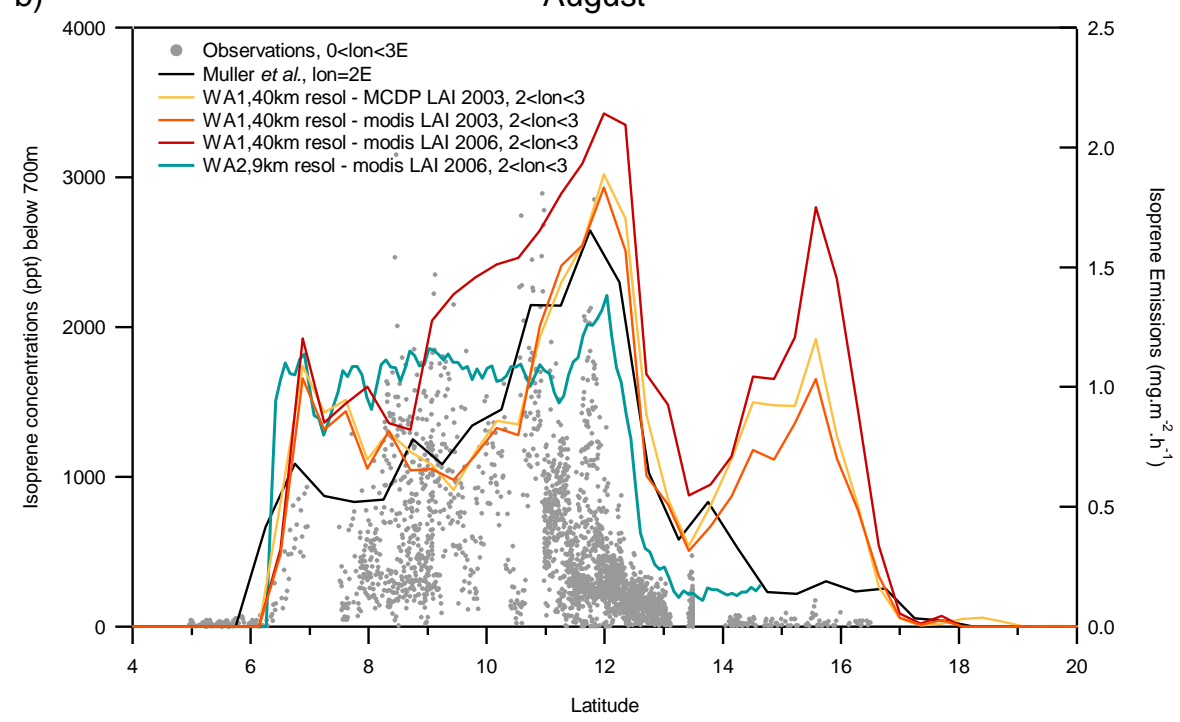

Fig. 8. Latitudinal variation of isoprene emissions for WA1 (based on the three sources of LAI data and on results obtained by Muller et al., 2007) and for WA2 (LAI MODIS 2006), and observed concentrations in (a) July and (b) August 2006.

very different, the modelled emissions again largely follow the radiation and exhibit a very different pattern to the observed isoprene mixing ratios.

Figure 10 also shows the downward short wave irradiance as observed on the aircraft. The data exhibited a great deal of variability such that much of it was flagged as not being good data (only the good data is shown). There is no clear relationship between the observed radiation and the isoprene, but if anything reductions in radiation and temperature (e.g. at $10.9^{\circ} \mathrm{N}$ and between 11.6 and $11.8^{\circ} \mathrm{N}$ ) are associated with increases in isoprene mixing ratios. There is also little agreement, if any, between the observed radiation and that of the model. It should be noted that the model output is an average for the hour and that as stated above changes considerably between the two hours during which the aircraft data were collected. Clearly this will impact the comparison between the modelled emissions, which are strongly dependent on the model radiation, and the observed isoprene concentrations.

Garcia-Carreras et al. (2010) examined the impact of land surface characteristics on the dynamics of the planetary boundary layer (PBL) during this same flight. They used isoprene mixing ratios in the low level run as a marker of vegetation type which exhibited a good correlation with the fraction of forest/shrub cover. It appears that higher evapotranspiration over the forest/shrub-land, which emit more isoprene than neighbouring cropland, leads to increased latent heat fluxes, an associated decrease in sensible heat fluxes and thus to cool PBL temperature anomalies. It is supposed that 

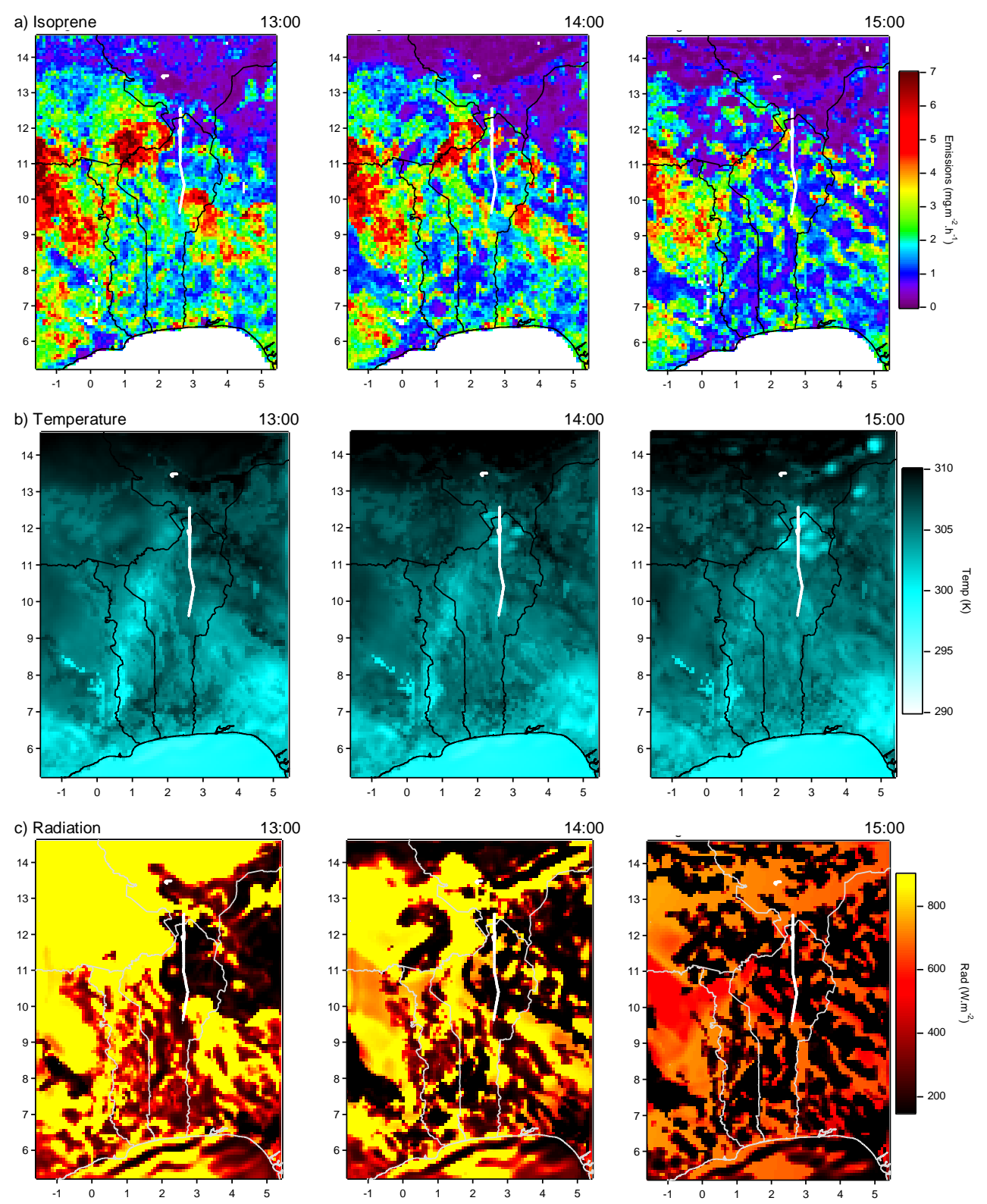

Fig. 9. Hourly surface fields of isoprene emissions $\left(\mathrm{mg} \mathrm{m}^{-2} \mathrm{~h}^{-1}\right)$ estimated by MEGAN at $9 \mathrm{~km}$ horizontal resolution (a), and temperature (K) (b) and radiation $\left(\mathrm{W} \mathrm{m}^{-2}\right.$ ) (c) simulated by MM5 at 13:00, 14:00 and 15:00 for 17 August 2006. The flight track of the low level run of flight B235 is shown by the white line.

the temperature gradients around these temperature anomalies then initiate land surface induced flows or vegetations breezes, which then form the convection. Since there is likely a strong vertical profile in isoprene, even within the mixed layer, shallow convection will push higher isoprene aloft, to the level of the aircraft. Further clouds will affect the chemistry through the photolysis rates, which in turn will also affect the lifetime of isoprene. At the scales of $10-50 \mathrm{~km}$ resolved by the aircraft, the presence of clouds, which control the radiation pattern at the surface, is linked to dynamical circulations in the boundary layer. These circulations are also redistributing isoprene on timescales comparable to its lifetime. Therefore the observations show patterns of isoprene that are dominated by the boundary-layer circulations, as well as the emissions. The transport of isoprene has not been modelled - just its emissions in MEGAN - and therefore the effects of mesoscale transport described by Garcia-Carreras et al. (2010) explain the lack of correspondence between isoprene observations and modelled emissions in Fig. 10. 

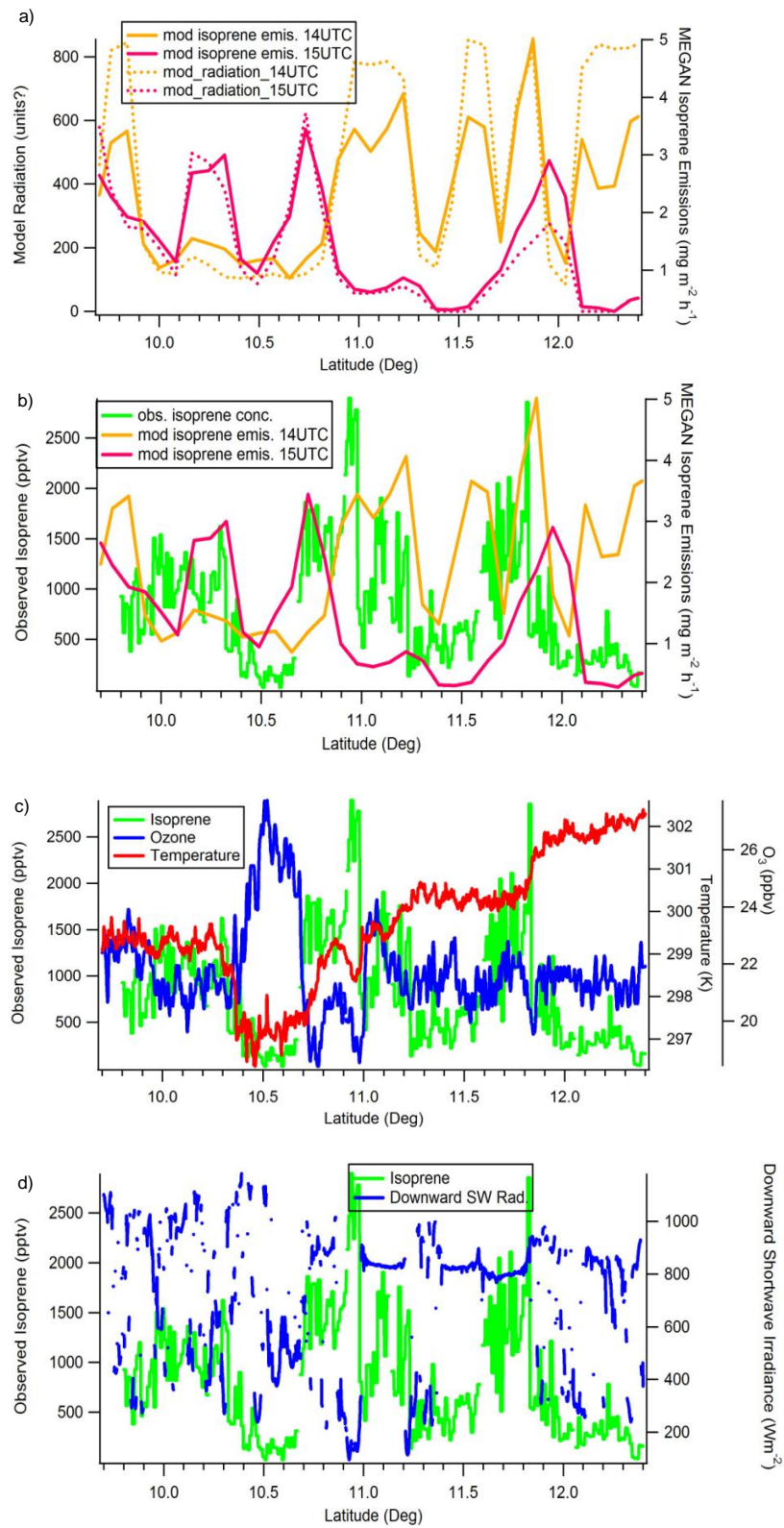

Fig. 10. The latitudinal variation of various parameters along the flight track of the low level run of flight B235 between 13:35 and 14:30 UTC on 17 August 2006: modelled isoprene emissions rates and MM5 radiation for 14:00 and 15:00 UTC (a), observed and modeled isoprene (b), observed isoprene, ozone mixing ratios and temperature (c), observed isoprene and downward short wave radiation (d).

This demonstrates that, in addition to strong relationships between meteorological factors and emissions of isoprene, there are very complex interactions between the land surface characteristics, the dynamics of the PBL and thus on the transport and chemistry of isoprene. Not only does this limit any comparison between calculated emissions and observed mixing ratios and isoprene, but it also illustrates the complex- ity of the processes that need to be represented in chemical transport models when simulating the impact of isoprene on tropospheric chemistry.

\section{Conclusions}

This paper presents an evaluation of the emissions of isoprene calculated using MEGAN for West Africa using observations of isoprene mixing ratios in the PBL. It represents a significant advancement in the evaluation of MEGAN for this region and thus is an important contribution to AMMA which aims to quantify the role of the West African Monsoon system in the emission of biogenic species and their impact on the global atmosphere.

The sensitivity analysis performed provides insight on the model behaviour, its response to input data changes and the influence of each driving variable on the model results. The LAI and emissions factors have the greatest impact on the large scale spatial distribution of the monthly average emission rates.

These large scale spatial distributions of emissions (at $40 \mathrm{~km}$ resolution) are generally in good agreement with those of the observed mixing ratios, with higher values over the forested regions south of $12^{\circ} \mathrm{N}$ and lower values to the north over the rainfed cropland and bare soil. There are, however, discrepancies identified over the bare soil around $16^{\circ} \mathrm{N}$, which point to the need to improve the emission factors in this region.

The increase of horizontal resolution to $9 \mathrm{~km}$ allows MEGAN to simulate a region of reduced emissions over crop land of around $60 \mathrm{~km}$ in extent that is characterised by lower PBL isoprene mixing ratios as observed repeatedly on several flights. Increasing the model resolution both spatially and temporally also illustrates how the non-linearity of the relationship between the isoprene emissions and radiation and temperature can be an important factor in model calculations. Furthermore, for case studies involving temporal resolutions of around an hour, the meteorological parameters, which are known to be highly uncertain, are likely to be critical, and for features of a few tens of kilometres in length the meteorology may be coupled to the land surface characteristics.

This study highlights the complex interactions between land surface processes and the meteorological dynamics and chemical composition of the PBL. This has implications for quantifying the impact of biogenic emissions on the atmospheric composition over West Africa and any changes that may occur with changing climate. 
Acknowledgements. Based on a French initiative, AMMA was built by an international scientific group and is currently funded by a large number of agencies, especially from France, the UK, the US and Africa. This work was funded by the EU and by the UK Natural Environment Research Council through the AMMA-UK Consortium grant and the National Centre for Atmospheric Science.

The authors are grateful to Alex Guenther and Tiffany Duhl for their help to run MEGAN and to Emmanouil Flaounas and Sophie Bastin (IPSL/Service d'Aeronomie, France) for the WRF meteorological modelling results provided.

Edited by: T. Karl

\section{References}

Aghedo, A. M., Schultz, M. G., and Rast, S.: The influence of African air pollution on regional and global tropospheric ozone, Atmos. Chem. Phys., 7, 1193-1212, doi:10.5194/acp-7-11932007, 2007.

Agusti-Panareda, A., Beljaars, A., Cardinali, C., Genkova, I., and Thorncroft, C.: Impact of assimilating AMMA soundings on ECMWF analyses and forecasts, Weather Forecast., 25(4), 1142-1160, doi:10.1175/2010WAF2222370.1, 2010.

AMMA web site: http://www.amma-international.org, last access: December 2009.

Andreae, M. O., Chapuis, A., Cros, B., Fontan, J., Helas, G., Justice, C., Kaufman, Y. J., Minga, A., and Nganga, D.: Ozone and Aitken Nuclei over Equatorial Africa-Airborne Observations During Decafe-88, J. Geophys. Res.-Atmos., 97, 61376148, 1992.

Ashworth, K., Wild, O., and Hewitt, C. N.: Sensitivity of isoprene emissions estimated using MEGAN to the time resolution of input climate data, Atmos. Chem. Phys., 10, 1193-1201, doi:10.5194/acp-10-1193-2010, 2010.

Bechara, J., Borbon, A., Jambert, C., Colomb, A., and Perros, P. E.: Evidence of the impact of deep convection on reactive volatile organic compounds in the upper tropical troposphere during the AMMA experiment in West Africa, Atmos. Chem. Phys. Discuss., 9, 20309-20346, doi:10.5194/acpd-9-20309-2009, 2009.

Cros, B., Fontan, J., Minga, A., Helas, G., Nganga, D., Delmas, R., Chapuis, A., Benech, B., Druilhet, A., and Andreae, M. O.: Vertical profiles of ozone between 0 meters and 400 meters in and above the African Equatorial Forest, J. Geophys. Res.-Atmos., 97, 12877-12887, 1992.

Delmas, R., Lacaux, J. P., Menaut, J. C., Abbadie, L., Leroux, X., Helas, G., and Lobert, J.: Nitrogen Compound Emission from Biomass Burning in Tropical African Savanna Fos/Decafe - 1991 Experiment (Lamto, Ivory-Coast), J. Atmos. Chem., 22, 175193, 1995.

Delmas, R. A., Druilhet, A., Cros, B., Durand, P., Delon, C., Lacaux, J. P., Brustet, J. M., Serca, D., Affre, C., Guenther, A., Greenberg, J., Baugh, W., Harley, P., Klinger, L., Ginoux, P., Brasseur, G., Zimmerman, P. R., Gregoire, J. M., Janodet, E., Tournier, A., Perros, P., Marion, T., Gaudichet, A., Cachier, H., Ruellan, S., Masclet, P., Cautenet, S., Poulet, D., Biona, C. B., Nganga, D., Tathy, J. P., Minga, A., Loemba-Ndembi, J., and Ceccato, P.: Experiment for Regional Sources and Sinks of Ox- idants (EXPRESSO): An overview, J. Geophys. Res.-Atmos., 104, 30609-30624, 1999.

Dudhia, J.: A nonhydrostatic version of the Penn State - NCAR Mesoscale Model: Validation tests and simulation of an Atlantic cyclone and cold front, Mon. Weather Rev., 121, 1493-1513, 1993.

Fehsenfeld, F., Calvert, J., Fall, R., Goldan, P., Guenther, A. B., Hewitt, C. N., Lamb, B., Liu, S., Trainer, M., Westberg, H., and Zimmerman, P.: Emissions of volatile organic compounds from vegetation and the implications for atmospheric chemistry, Global Biogeochem. Cy., 6, 390-430, 1992.

Flaounas, E., Bastin, S., and Janicot, S.: Regional climate modelling of the 2006 West African monsoon: sensitivity to convection and planetary boundary layer parameterisation using WRF, Clim. Dynam., Online First, 1-23, doi:10.1007/s00382010-0785-3, 2010.

Fontan, J., Druilhet, A., Benech, B., Lyra, R., and Cros, B.: The Decafe Experiments - Overview and Meteorology, J. Geophys. Res.-Atmos., 97, 6123-6136, 1992.

Garcia-Carreras, L., Parker, D. J., Taylor, C. M., Reeves, C. E., and Murphy, J. G.: Impact of mesoscale vegetation heterogeneities on the dynamical and thermodynamic properties of the planetary boundary layer, J. Geophys. Res., 115, D03102, doi:10.1029/2009JD012811, 2010.

Greenberg, J. P., Guenther, A. B., Madronich, S., Baugh, W., Ginoux, P., Druilhet, A., Delmas, R., and Delon, C.: Biogenic volatile organic compound emissions in central africa during the experiment for the regional sources and sinks of oxidants (expresso) biomass burning season, J. Geophys. Res.-Atmos., 104, 30659-30671, 1999.

Greenberg, J. P., Guenther, A., Harley, P., Otter, L., Veenendaal, E. M., Hewitt, C. N., James, A. E., and Owen, S. M.: Eddy flux and leaf-level measurements of biogenic voc emissions from mopane woodland of botswana, J. Geophys. Res.-Atmos., 108, 8466-8474, 2003.

Grell, G. A., Dudhia, J., and Stauffer, D. R.: A description of the fifth-generation Penn State/NCAR mesoscale model (MM5), NCAR/TN-398 STR, Penn State/NCAR, 1994.

Guenther, A., Hewitt, C. N., Erickson, D., Fall, R., Geron, C., Graedel, T., Harley, P., Klinger, L., Lerdau, M., McKay, W. A., Pierce, T., Scholes, B., Steinbrecher, R., Tallamraju, R., Taylor, J., and Zimmerman, P.: A global model of natural volatile organic compound emissions, J. Geophys. Res., 100, 8873-8892, 1995.

Guenther, A., Otter, L., Zimmerman, P., Greenberg, J., Scholes, R., and Scholes, M.: Biogenic hydrocarbon emissions from southern african savannas, J. Geophys. Res.-Atmos., 101, 25859-25865, 1996.

Guenther, A., Baugh, B., Brasseur, G., Greenberg, J., Harley, P., Klinger, L., Serca, D., and Vierling, L.: Isoprene emission estimates and uncertainties for the central african expresso study domain, J. Geophys. Res.-Atmos., 104, 30625-30639, 1999.

Guenther, A., Karl, T., Harley, P., Wiedinmyer, C., Palmer, P. I., and Geron, C.: Estimates of global terrestrial isoprene emissions using MEGAN (Model of Emissions of Gases and Aerosols from Nature), Atmos. Chem. Phys., 6, 3181-3210, doi:10.5194/acp-63181-2006, 2006.

Harley, P., Monson, R., and Lerdau, M.: Ecological and evolutionary aspects of isoprene emission from plants, Oecologia, 118, 
109-123, 1999.

Janicot, S., Thorncroft, C. D., Ali, A., Asencio, N., Berry, G., Bock, O., Bourles, B., Caniaux, G., Chauvin, F., Deme, A., Kergoat, L., Lafore, J.-P., Lavaysse, C., Lebel, T., Marticorena, B., Mounier, F., Nedelec, P., Redelsperger, J.-L., Ravegnani, F., Reeves, C. E., Roca, R., de Rosnay, P., Schlager, H., Sultan, B., Tomasini, M., Ulanovsky, A., and ACMAD forecasters team: Large-scale overview of the summer monsoon over West Africa during the AMMA field experiment in 2006, Ann. Geophys., 26, 25692595, doi:10.5194/angeo-26-2569-2008, 2008.

Jonquieres, I., Marenco, A., Maalej, A., and Rohrer, F.: Study of ozone formation and transatlantic transport from biomass burning emissions over West Africa during the airborne Tropospheric Ozone Campaigns TROPOZ I and TROPOZ II, J. Geophys. Res.Atmos., 103, 19059-19073, 1998.

Kavouras, I. G., Mihalopoulos, N., and Stephanou, E. G.: Formation of atmospheric particles from organic acids produced by forests, Nature, 395, 683-686, 1998.

Klinger, L. F., Greenberg, J., Guenther, A., Tyndall, G., Zimmerman, P., M'Bangui, M., and Moutsambote, J. M.: Patterns in volatile organic compound emissions along a savanna rainforest gradient in central africa, J. Geophys. Res.-Atmos., 103, 14431454, 1998.

Lamb, B., Guenther, A., Gay, D., and Westberg, H.: A national inventory of biogenic hydrocarbon emissions, Atmos. Environ., 21, 1695-1705, 1987.

Loreto, F. and Sharkey, T. D.: A gas-exchange study of photosynthesis and isoprene emission in Quercus rubra L., Planta, 182, 523-531, 1990.

MEGAN Data Portal: http://acd.ucar.edu/ guenther/MEGAN/ MEGAN.htm, last access: January 2010, http://cdp.ucar.edu/, last access: January 2010.

Monson, R., Hills, A., Zimmerman, P., and Fall, R.: Studies of the relationship between isoprene emission rate and $\mathrm{CO}_{2}$ or photonflux density using a real-time isoprene analyzer, Plant Cell Environ., 14, 517-523, 1991.

Müller, J.-F., Stavrakou, T., Wallens, S., De Smedt, I., Van Roozendael, M., Potosnak, M. J., Rinne, J., Munger, B., Goldstein, A., and Guenther, A. B.: Global isoprene emissions estimated using MEGAN, ECMWF analyses and a detailed canopy environment model, Atmos. Chem. Phys., 8, 1329-1341, doi:10.5194/acp-81329-2008, 2008.

Murphy, J. G., Oram, D. E., and Reeves, C. E.: Measurements of volatile organic compounds over West Africa, Atmos. Chem. Phys., 10, 5281-5294, doi:10.5194/acp-10-5281-2010, 2010.

National Centre for Environmental Prediction (NCEP) global 1degree reanalysis data updated every 6-hours: http://dss.ucar. edu/datasets/ds083.2/data/, last access: October 2008.

Otter, L. B., Guenther, A., and Greenberg, J.: Seasonal and spatial variations in biogenic hydrocarbon emissions from southern african savannas and woodlands, Atmos. Environ., 36, 4265$4275,2002$.
Otter, L., Guenther, A., Wiedinmyer, C., Fleming, G., Harley, P., and Greenberg, J.: Spatial and temporal variations in biogenic volatile organic compound emissions for africa south of the 30 equator, J. Geophys. Res.-Atmos., 108, SAF41.1-SAF41.12, 2003.

Pfister, G. G., Emmons, L. K., Hess, P. G., Lamarque, J. F., Orlando, J. J., Walters, S., Guenther, A., Palmer, P. I., and Lawrence, P. J.: Contribution of isoprene to chemical budgets: A model tracer study with the ncar ctm mozart-4, J. Geophys. Res.-Atmos., 113, D05308, doi:10.1029/2007JD008948, 2008.

Reeves, C. E., Formenti, P., Afif, C., Ancellet, G., Attie, J.-L., Bechara, J., Borbon, A., Cairo, F., Coe, H., Crumeyrolle, S., Fierli, F., Flamant, C., Gomes, L., Hamburger, T., Lambert, C., Law, K. S., Mari, C., Matsuki, A., Methven, J., Mills, G. P., Minikin, A., Murphy, J. G., Nielsen, J. K., Oram, D. E., Parker, D. J., Richter, A., Schlager, H., Schwarzenboeck, A., and Thouret, V.: Chemical and aerosol characterisation of the troposphere over West Africa during the monsoon period as part of AMMA, Atmos. Chem. Phys. Discuss., 10, 7115-7183, doi:10.5194/acpd-10-7115-2010, 2010.

Sauvage, B., Thouret, V., Cammas, J.-P., Gheusi, F., Athier, G., and Nédélec, P.: Tropospheric ozone over Equatorial Africa: regional aspects from the MOZAIC data, Atmos. Chem. Phys., 5, $311-$ 335, doi:10.5194/acp-5-311-2005, 2005.

Sauvage, B., Thouret, V., Cammas, J. P., Brioude, J., Nédélec, P., and Mari, C.: Meridional ozone gradients in the African upper troposphere, Geophys. Res. Lett., 34, L03817, doi:10.1029/2006GL028542, 2007.

Serca, D., Guenther, A., Klinger, L., Vierling, L., Harley, P., Druilhet, A., Greenberg, J., Baker, B., Baugh, W., Bouka-Biona, C., and Loemba-Ndembi, J.: Expresso flux measurements at upland and lowland congo tropical forest site, Tellus B, 53, 220-234, 2001.

Sijikumar, S., Roucou, P., and Fontaine, B.: Monsoon onset over Sudan-Sahel: Simulation by the regional scale model MM5, Geophys. Res. Lett., 33(3), L03814, doi:10.1029/2005GL024819, 2006

Sowden, M., Zunckel, M., and Van Tienhoven, A. M.: Assessment of the status of biogenic organic emissions and impacts on air quality in southern Africa, Tellus, 59B, 535-541, 2007.

Williams, J. E., Scheele, M. P., van Velthoven, P. F. J., Cammas, J.-P., Thouret, V., Galy-Lacaux, C., and Volz-Thomas, A.: The influence of biogenic emissions from Africa on tropical tropospheric ozone during 2006: a global modeling study, Atmos. Chem. Phys., 9, 5729-5749, doi:10.5194/acp-9-5729-2009, 2009.

WRF Weather Research and Forecasting Model: http://www wrfmodel.org/, last access: January 2010. 